they might perhaps (from what has been said) be more
properly called. is certainly a most curious feature in the geology of $N \in \mathbb{C}$ Caledonia, scarcely less extraordinsaid to be famed, and possibly the color of the latter may have some connection with the presence of these pears to be colored red by nature that it seems quite a pity in fact it is not red on the map.
The clays or earths are believed by Levat to be the products of the hydrothermal decomposition of the
serpentines, as they contain all the elements of these serpentines, as they contain all the elements of these
rocks, in addition toiron, manganese, chromium, and cobalt. He supposes that numerous iron and manganiferous springs found vent through fissures in the serpen-
tine and have eaten it away, leaving half dissolved masses of so-called sugar rock in the clay that fills the of oolitic iron ore, the prodnct of the overflow of the
ferruginous waters. Mr. Garland's observations that th ferruginous waters. Mr. Garland's observations that the
ore is found in massive pieces in botryoidal, mammil lated, and occasionally in stalactitic forms, and in brec-
ciated masses, supports this view. It has been pointed out also as a remarkable fact that these deposits are
mostly found at high altitudes (the mountains of the interior rising to a height of 5,576 feet, and averaging
1,640 feet), and in the lower-lying serpentine areas the are non-existent, but tion, if we suppose that the serpentines are the altered
products of volcanic action which overflowed in the in terior of the island, as it is just there that the condiof the minerals we have under review, under such circumstances. Veins of chrome iron ore also occur in while cobalt ore is likewise found in the red earths, the
origin of which latter deposits is considered by Levat was derived from it, while the nickel solutions only appeared after the deposition of the clay.
These solutions, circulating not only on the contact, but in the cracks and joints of the adjacent serpentine,
would explain the deposition of the.hydrated silicate of magnesium and nickel, in "Stockwerk form," which is, however, also largely found, according to Levat, in
a brecciated form on the roof or walls of the basins of red earth, being sometimes symmetrically deposited,
when the axis of the basin is vertical (in which case the ore is of equal thickness on the walls); at other times
the axis of the basin is inclined, and the serpentine which forms the roof is fissured the cracks so found
being often several meters wide, filled with rich ore, the nickeliferous solutions, being unable to penetrate the clay, finding a natural passage along the walls of the
cavities. Where the circulating waters moved for a long time between the walls and the clay, fine strim
are found upon the latter (Annales des Mines, second are found upon the latter (Annales des Mines, second
livraison). Levat further states that the nickel deposits lie.in a series of zones, running northeast and to the interior, and continuing, as Mr. Garland points out, to the west coast; outside of them there
local encroachments, which lack uniformity.

the deepest workings the time Levat examined them, the deepest workings were only down 275 feet below lose their thickness, basing his opiuion on the probability that the red earths with which they appear con-
nected would 'not hold down to any great depth. Levat summarizes the general characteristics as fol-
lows : 1 . The ore is essentially dependent on the ser lows: 1 . The ore is essentially dependent on the ser-
pentine of the east and southeast parts of the island. 2. Ores of cobalt, associated with manganese, are found
in beds on the rim of the basins of the earth found traversing the serpentine in a number of places. These cobalt ores do not contain over two or tbree per cent.
of Co, but they are very extensive, being inined simply
by scraping up the waterial. 3 The deposits of chroby scraping up the naterial. 3. The deposits of ehro-
mium are of two kinds. either in veins in the serpentine or in stratified beds in the basins of earth. 4 .
The nickel deposits are of later formation than either at or in the neighborhood of the contact of these clays or earths with the serpentine, and never in the body of
the former. They are united in a certain number of northeast and southwest lines, the width of which
does not exceed, as before said, 600 meters. does not exceed, as before said, 600 meters.
The crystalline dialage, being less attacked than the other constituents of the serpentine by the minera
solutions which have eaten it away, forms a skeleton which is sought for by the miners as an indication of ore.
Tissure lodes appear to be absent, but some of the distances alony their strike, possess/ regular walls and
dip, have a width of 18 inches to 5 feet, and have been dip, have a width of 18 inches to 5 feet, and have been
followed down, in one instance, to a depth of 360 feet below the surface outerop.

As the formation of the deposits in the basins of red earth is due, Levat thinks, to the shrinkage of those
clays, their continuity in depth may probably depend, as he supposes, on the depth of the clays in the basins. It must not be supposed, however, that these deposit
are likely to be speedily exhausted, as they have a very
wide distribution indeed. wide distribution indeed. They are mined in open
quarries, in benches, when found as stock works; at quarries, in benches, when found as stock works ; at
menced by removing the red clay, which, if mixed with the ore, entails difficulties, as the grains of iron are
with great difficulty separated by washing, and conwith great difficulty separated by washing, and con-
sequently appear in the matte produced. Moreover, the clay, being very aluminous (according to Levat),

renders the siliceous ore still more refractory.
The gravity system of transport on a single rope at
these mines is certainly extremely primitive, but is no doubt due to the necessity of frequently shifting the
position of the terminals. It might, however, be imposition of the terminals. It might, however, be im-
proved upon by hauling up the empty bags and car-
riers on a carriage attached to the main cable by means of a small hoisting rope, operated by a windlass, in stead of carrying them up, as is now done, on men's shoulders. The principle of using gravity inclines
with double ropes has beert satisfactorily employed
underground at the Pierrefitte mines in the Pyrenees,

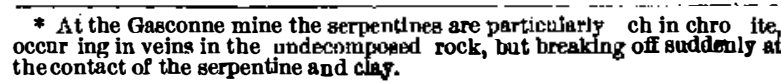
in large open gunnices; the only instance I know of
where such a system has been operated underground.
It was introduced because the flatness of the lode
would have involved shoveling, and it possesses ob-
vious advantages over an inclined plane, for a short
temporary roadway in lofty workings.
According to $\mathrm{Mr}$. Ph. Argall (quoting, I believe,

According to Mr. Ph. Argall (quoting, I believe,
from official sources), the output of nickel and cobalt
ore from New Caledonia, in 1890 was 22,690 tons of (sar) ore from New Caledonia, in 1890 , was 22,690 tons of (say) cobalt ore, while, in 1891, the output of nickel ore had
only reached 35,000 tons. Mr. Garland states, on the orer hand, that these mines are now producing over 30,000 tons of nickel ore per annum : and to reconcile
the two statements, I take it that he alludes to the per ton. He puts the cost of mining at 6s. to 40.
The first mechanical treatment of the ore consists of orting and washing at the quarries, where a division is made into rich ore, carrying 8 per cent. and over of
nickel, and poor ore under that amount. The ore is then carried to the plain below to be washed, so as to gravity asthe serpentine, but less than the iron. The
ore rejected at the quarry, although it contains 3 or 4 per cent. of nickel, is of no value. Garnier's first idea
was to treat the ore in a blast furnace, to obtain crude nickel and refine it; but this latter process
presented such diffeulties that it was abandoned. Fusion for matte was then tried but was also given up, owing to the high price of fuel and the inefficienc nickel, dealing with such ores, appears to be--mining and transport, 10 cents ; conversion into oside, 3 cents reduction into metal, 8 cents; allowat
working, 1 cent; total, 22 cents.
(To be continued.)

\section{THREE YEARS IN A COUNTRY GAS}

By S. M. Highlands, of Clinton, Iowa.

I Do not think it is possible for me to add anythirg the idea that the business was hedged around with too has been allowed to grow around it was one of the
greatest drawbacks with which it had to contend. In the smaller cities the gas superintendent is alone, and his business a mysterious one; that he is the only man n the communify who can master its intricate details to their senses about the electric light craze, and every It occurred serene.

It occurred to me some years ago that this was al their convictions is a slow and unprofitable proceeding; and that gas is only a commodity that people can either use or dispense with without very much inare most successful in other lines of business could bo fully believe that the unparalleled growth of the popular, without regard to any immediate profits.

Infused with these ideas, I assumed the management
of the Clinton (Ia.) gas works on April 1, 1891. Th works were the usual 6 inch coal gas works and were
built in 1871 . In 1875 they sold $5,500,000$ feet of gas. In 1884 it had increased to 6,122,000 feet. In 1886 the in 1890 it had risen again to $6.491,000$ feet, with the price of gas ranging from $\$ 2$ to $\$ 2.50$ per 1,000 .
$0 n$ April 1,1891 , the price was reduced to $\$ 1.75$ for illuminating and $\$ 1.25$ for fuel ; and a c contract was of the new nanagement, the old adage, "The outse regarded. The only aim was to make the kind of gas he public would use the most of, without mue whether it took 4 or $51 / 2$ gallons of oil, or 35 or 50 pounds
of coal to the 1,000 feet. We believed then, as we be ieve now, that the prineipal duties of a gas manage were to sell gas, and that the making of it was a minor
incident connected with the business; that the margin between the cost in the holder and the usual selling afford to have the cosi inereased by 10 to 15 per cent. if by so doing he could devote more of his time to seli-
ing it and thereby increase his sales. I will venture ing it and thereby increase his sales. I will venture would take and pay for, if he could only make it to
wall their interest to do so.
In carrying out this idea, we advertised that for year we would run free service pipes; sell gas stoves a cost : pipe buildings free; and in a great many places
we furnished gas fixtures free. At this time the company had only 235 meters set and not a gas stove in we had from 15 to 25 gasfitters at work, and during the ating purposes. This work cost the company about
at,000, and you can judge for yourselves whether it is worth this sum to add 577 new customers to a plant
that only had 235 to begin with. By September 1 , we and thought a fight with them would advertise us, i nothing else. We sent a canvasser to all their custom half the price they were paying for electric light, generally allowing the customer to say how many gas jet
he would need to properly light his place. They had 53 customers, and we took 45 of them on this proposi-
tion and had them tied up for one year. This action on our part forced them to sell out to us at once at our
price and we failed to have any fun outof the scheme a all. We metered the 45 contract custoners just as care fully as we did the regular ones and took the state-
ments monthly. It might be as well to state here that ments monthly. It might be as well to state here that
these contracts raised a new question in our minds * A aper resd before the Weatern Gas Associastion, Cleveland.-Ameni-
can $Q$ Qas Light Joumal. that we will take up some time and settle to our ow Please remember that all this occurred in a small quainted with each of his customers and know what
they were doing; and this article is supposed to be of
no benefit to the larger cities. Those 45 contract customers were put on without any idea of naking very much money out of them, but rather to force a fight on the electric company. We knew when we took them that some of them would get pretty cheap gas, and we
were not disappointed. During the year for which they run, they used $2,894,000$ feet, for which they paid 00,000 feet; and in July, 122,200; one of the largest ing only 40 cents per 1,000 , while some of them wer ing only 40 cents per 1,000 , while
paying as high as $\$ 1.50$ per 1.000 .

We bought the electric light plant in December, 1891 and inmediately reduced the price of electric lights 25 per cent, making the rate forarc light of 2,000 candle
power $\$ 6$ per month, for 9 o'clock lights, and $\$ 8$ for the option of surrendering their gas contracts and tak
ing the electric light at the new price; but none of
them availed themselves of the privilege. At the end of the year none of the contracts were renewed. About
one-half of them are now using gas and the rest have one-half of them are now using
returned to the electric light.

e found a great nany customers who thought they try gas for illuminating purposes; and for such custoners we always put a gas burner over or near the was that in a short time the man of the house would come to the office and say that he was tried of sitting
in the kitchen to read, and wanted one light in his sitting room; and this was followed by several more in ther parts of the house at the illuminating rate.
Our office is kept open from $7 \mathrm{~A}$. M. to 9 P. M., and all complaints are taken care of within an hour of their being made. A meter prover is kept in the office ; him to wait and see it brought in and tested. We
are always willing to settle with him on the basis hown by the prover. I have yet to find the custom who was not perfectly satisfied after seeing this tes
made, and agreed with us that if there was anything wrong with his bill, the fault was at his house and not Another imperative rule is that while we now have a monopoly of the lighting business, our customers
should not find out that we know it; they should al er mercantile house; a trivial complaint should be treated with as much considerai ion as the most seri-
ous one. Another rule that will have more weight with them than all others is, whatever we do must be well done. Nothing temporary allowed, and never
makeshift. In rebuilding the gas works, money was not spared plant, the very best Corliss engines and high grade boilers were used. The results are that "no gas" com-
plaints are rarely, if ever, heard. and we have not had a claim for rebate on account of "electric light out"
for over two years. Our electric service has been so good that the city has just closed a contract with us
for all their street lights for a period of 12 years, and the electric street railroad has contracted with us for its power for 7 years.

There have been no changes in prices on the gas for
years: and for the past 2 years we have been charg ing a fair price for all service work, also for all electric wiring and renewals. In the meantime, the growth
of the gas business has been much more rapid than that of the electric business.

As I stated before, the company sold $6,491,000 \mathrm{ft}$. of
As in to 235 customers in the year 1890 . In 1891 they gold to 235 customers in the year 1890 . In 1891 they tomers. At this time-January 1, 1892-we had $50 \mathrm{com}$ mercial are lights and 800 incandescent ones. For the
year ending January 1,1893 , we sold $18,000,000 \mathrm{ft}$. of in the year ending January 1,1894 , our sales of gas had increased to over $20,000,000 \mathrm{ft}$. to 977 customers; while 1,200 incandescents, exclusive of the street lighting. With the street lighting and street railroad work, the
gross business of the electric light plant is larger than gross business of the electric light plant is larger than
the gas business, but is, of course, a great deal more expensive to us to furnish. On the whole, we are satis gas just as readily as that of any other commodity, very small figure in small cities.

As some of you probably know, we also supply gas
o Lyons, a city of some 7.000 inhabitants, immediateto Lyons, a city of some 7.000 inhabitants, immediate-
ly adjoining Clinton. Lyons has a municipal electric plant has been established some 10 years, while the gas mains ween onty run 3 years ago. At the time we and shops were using the electric light. We did not make any effort to displace the electric light, but in-
stead concluded we would see what a fair competition between gas at $\$ 1.75$ per thousand and are lights at . the stores. A customer would use the gas through the winter when the evenings were long. In the summer
of 1893 we sent 50 Welsbach burners up there to see what they would do. We equipped one large jewelry results. And they have been surprising, indeed; for today there is not one store in the city using electric lights. the Welsbach burners having entirely displaced
them; but at the same time it has cut down our sales of gas, and I do not know but that we had better let get rid of the Welsbach burners. The burners are all qualified satisfaction; but the confounded things won't let any gas through them. The same jewelry store that was formerly using two are lights only used 3,000 ft. at Lyons, we would prefer furnishing e
rather than Welsbach burners in Clinton. 